Pediat. Res. 4: 309-317 (1970)

Congenital adrenal hormones hyperplasia precocious puberty gonads testosterone

\title{
Excretion and Production of Testosterone in Normal Children, in Children with Congenital Adrenal Hyperplasia, and in Children with Precocious Puberty
}

\author{
H.J.Degenhart ${ }^{[53]}$, H. K.A.Visser and R.WILmink \\ Department of Pediatrics, Rotterdam Medical School, Rotterdam, The Netherlands
}

\begin{abstract}
Extract
Testosterone, both in a free and in a conjugated form, hydrolyzable by snail $\beta$-glucuronidase and sulfatase, was extracted from the urine of children and measured by forming ${ }^{14} \mathrm{C}$-acetate derivatives. Administration of ${ }^{3} \mathrm{H}$-labeled testosterone permitted estimation of rates of production. Study of 10 normal prepubertal children (group $A$ ), varying in age from $8 / 12$ to $10^{9} / 12$ years, yielded excretion values of $0.3-6.3 \mu \mathrm{g} / 24 \mathrm{~h}$ (mean $2.1 \mu \mathrm{g} / 24 \mathrm{~h}$ ) and production rates of 16-880 $\mu \mathrm{g} / 24 \mathrm{~h}$ (mean $274 \mu \mathrm{g} /$ $24 \mathrm{~h}$ ). Mean ratio of excretion to production was $0.6 \%$. A linear correlation between testosterone excretion and age could be demonstrated.

These values were compared with those obtained from 13 children suffering from congenital adrenal hyperplasia $(\mathrm{CAH})$ caused by a deficiency of 21-hydroxylase (group $B$ ) and with those of 4 children with idiopathic precocious puberty (PP) (group $C$ ). In children of group $B$, increased androgenic activity could be demonstrated. Excretion values of testosterone varied from 11 to 261 $\mu \mathrm{g} / 24 \mathrm{~h}$ (mean $98 \mu \mathrm{g} / 24 \mathrm{~h}$ ). Mean production-to-excretion ratio was $0.6 \%$. It could be calculated, however, that free testosterone secreted by the adrenals represented only a small percentage of the total production. By far the largest part was derived from two other adrenal hormones: androstenedione and dehydroepiandrosterone. In these cases, however, rates of testosterone production and excretion can still give a valuable indication of the total androgenic activity.

Children in group $C$ showed elevated production values as well: $540-1,900 \mu \mathrm{g} / 24 \mathrm{~h}$ (mean 1,180 $\mu \mathrm{g} / 24 \mathrm{~h}$ ). After receiving HCG (human chorionic gonadotropin) for 3 days $(3,000 \mathrm{U} / 24 \mathrm{~h})$ the range was $1,250-3,400 \mu \mathrm{g} / 24 \mathrm{~h}$ (mean $2,460 \mu \mathrm{g} / 24 \mathrm{~h}$ ).
\end{abstract}

\section{Speculation}

A linear correlation exists between rates of excretion of testosterone and age in prepubertal children. Very young children (less than 12 months of age) may have higher levels. Rates of production of testosterone in urine are more useful than is generally thought. 


\section{Introduction}

During recent years the metabolism of testosterone has been intensively studied, under normal as well as pathological conditions, by a number of investigators. The excretion in the urine of testosterone glucuronide, as well as the plasma concentration of free testosterone has been determined. Recently reported values for excretion are $20-150 \mu \mathrm{g} / 24 \mathrm{~h}$ for adult males and 5-15 $\mu \mathrm{g} / 24 \mathrm{~h}$ for adult females; the plasma concentrations are approximately $0.7 \mu \mathrm{g} / 100 \mathrm{ml}$ and $0.04 \mu \mathrm{g} / 100 \mathrm{ml}$ for males and females, respectively $[10,13,17,32,37$, $40,41]$. Just as with other hormones such as hydrocortisone and aldosterone, the production rate of testosterone is determined from the cumulative specific activity of a urinary metabolite, i. e., testosterone glucuronide [16]. This urinary production rate (UPR) is approximately $7 \mathrm{mg} / 24 \mathrm{~h}$ for males and $1-2.5 \mathrm{mg} / 24 \mathrm{~h}$ for females $[14,16,24,39]$. For normal prepubertal children, only a few data are available. Some data on plasma concentrations were recently published by Frasier and Horton [9].

The excretion of testosterone glucuronide in the urine of children has been investigated by MaRoBerTs et al. [28], VESTERGAARD et al. [42], KNORR [19] and Gupta [11]. The methods used, however, were not sensitive enough in all cases, especially for values less than 2-3 $\mu \mathrm{g}$.

We are reporting in this study our data on excretion and production of testosterone in prepubertal, endocrinologically normal children. In addition, we studied the excretion and production of testosterone in children with congenital adrenal hyperplasia (CAH) (21hydroxylase deficiency), and in children with precocious puberty (PP) in whom a high production of androgens could be expected.

\section{Patients}

Excretion or production, or both, of testosterone was estimated in: group $A, 10$ children, endocrinologically normal $\left(A_{1}-A_{10}\right)$. During the investigation these children received no medication and were fed a normal diet. Group $B, 13$ patients with $\mathrm{CAH}$ caused by a steroid 21-hydroxylase deficiency $\left(B_{1}-B_{13}\right)$. The diagnosis, made on clinical grounds, was confirmed by the determination of pregnanetriol and 17-ketosteroids (table I). Sex and age are also shown in table I. Patients $B_{6}, B_{10}, B_{12}$, and $B_{13}$ had not been treated before being studied. The remaining patients had been treated with 5-15 $\mathrm{mg}$ hydrocortisone/24 $\mathrm{h}$ or the equivalent dose of prednisone (orally). Treatment was stopped I week before the investigations. Three patients, $B_{1}, B_{2}$, and $B_{3}$ were 'salt losers'. These patients received in addition to the treatment with glucocorticoids $2 \mathrm{mg}$ of Doca $/ 24 \mathrm{~h}$ (intramuscularly). The Doca
Table $I$. Data on children with congenital adrenal hyperplasia $^{1}$

\begin{tabular}{llccc}
\hline $\begin{array}{l}\text { Patient } \\
\text { nos. }\end{array}$ & Sex & $\begin{array}{c}\text { Age, } \\
\text { yr }\end{array}$ & $\begin{array}{c}\text { 17-Keto- } \\
\text { steroid, } \\
\text { mg/24h }\end{array}$ & $\begin{array}{c}\text { Pregnane- } \\
\text { triol, } \\
\mathrm{mg} / 24 \mathrm{~h}\end{array}$ \\
\hline$B_{1}$ & $\mathrm{M}$ & $3 / 12$ & 0.8 & 6 \\
$B_{2}$ & $\mathrm{~F}$ & $8 / 12$ & 0.4 & 3.5 \\
$B_{3}$ & $\mathrm{~F}$ & $4^{3} / 12$ & 8.1 & 10.5 \\
$B_{4}$ & $\mathrm{M}$ & 9 & 17.7 & 19 \\
$B_{5}$ & $\mathrm{M}$ & 14 & 23.5 & 15 \\
$B_{6}$ & $\mathrm{~F}$ & $2 / 12$ & 2.3 & 1 \\
$B_{7}$ & $\mathrm{M}$ & 4 & 2.3 & 8 \\
$B_{8}$ & $\mathrm{~F}$ & 5 & 2.2 & 6 \\
$B_{9}$ & $\mathrm{~F}$ & 8 & 5.7 & 9 \\
$B_{10}$ & $\mathrm{~F}$ & 13 & 37 & 30 \\
$B_{11}$ & $\mathrm{M}$ & $8^{3} / 12$ & 11.5 & 7.6 \\
$B_{12}$ & $\mathrm{M}$ & $9^{3} / 12$ & 12.2 & 9 \\
$B_{13}$ & $\mathrm{M}$ & $6^{7} / 12$ & 7.8 & 8.3 \\
\hline
\end{tabular}

1 Excretion values were obtained on the same day that excretion, or production, or both, of testosterone were studied.

was discontinued 2 days before the investigations. In some of the patients the estimation of excretion and production of testosterone was not done at the same time. In table II, the ages of the children are given at the time of the investigation of excretion and production of testosterone. Patient $B_{13}$ was reinvestigated on treatment, 1 month after the first study. Group $C$, 4 patients $\left(C_{1}-C_{4}\right)$ with idiopathic PP. They had not been treated before this study. Urinary production rate (UPR) of testosterone in these patients was estimated after 3 days of human chorionic gonadotropin administration (HCG, 3,000 U/24 h) [50].

\section{Materials and Methods}

${ }^{14} \mathrm{C}$-Acetic anhydride was obtained from a commercial source [44]. Specific activity of different batches was $10-25 \mathrm{mCi} / \mathrm{mm}$. It was used as quickly as possible, after dilution with 'cold' acetic anhydride to yield a specific activity of $4,000-20,000 \mathrm{dpm}{ }^{14} \mathrm{C} / \mu \mathrm{g}$ testosterone. A sensitivity of about $0.01 \mu \mathrm{g} / 24 \mathrm{~h}$ could be obtained in this way. $\left(4-{ }^{14} \mathrm{G}\right)$ Testosterone [45] (specific activity $20 \mathrm{mCi} / \mathrm{mm})$ and $\left(1,2-{ }^{3} \mathrm{H}\right)$ testosterone [46] (specific activity $30 \mathrm{Ci} / \mathrm{mm}$ ) were purified by chromatography before use. Several brands of $\mathrm{NaBH}_{4}$ were tried. The product of Koch-Light was found to be the most satisfactory for the reduction of the 3-keto groups. Solvents used were purified following standard procedures. 
Table II. Excretion and production of testosterone in children ${ }^{1}$

\begin{tabular}{|c|c|c|c|c|c|}
\hline \multirow{2}{*}{$\begin{array}{l}\text { Patient } \\
\text { nos. }\end{array}$} & \multirow[t]{2}{*}{ Sex } & \multicolumn{2}{|c|}{ Excretion } & \multicolumn{2}{|c|}{ Production } \\
\hline & & $\begin{array}{l}\text { Age, } \\
\text { yr }\end{array}$ & $\begin{array}{c}\text { Testosterone, } \\
\mu \mathrm{g} / 24 \mathrm{~h}\end{array}$ & $\begin{array}{l}\text { Age, } \\
\text { yr }\end{array}$ & $\begin{array}{c}\text { Testosterone, } \\
\mu \mathrm{g} / 24 \mathrm{~h}\end{array}$ \\
\hline$A_{1}$ & $\mathrm{~F}$ & - & - & $10^{5} / 12$ & 290 \\
\hline$A_{2}$ & $\mathrm{~F}$ & - & - & $4^{3} / 12$ & 16 \\
\hline$A_{3}$ & $\mathbf{F}$ & $10^{9} / 12$ & 6.3 & - & - \\
\hline$A_{4}$ & $\mathbf{M}$ & $6 \% 12$ & 2.7 & - & - \\
\hline$A_{5}$ & $\mathrm{M}$ & $8^{4} / 12$ & 4.2 & $84 / 12$ & 460 \\
\hline$A_{6}$ & $\mathrm{~F}$ & $10 / 12$ & 0.5 & $10 / 12$ & 45 \\
\hline$A_{7}$ & $\mathrm{~F}$ & $5^{6} / 12$ & 0.3 & $56 / 12$ & 104 \\
\hline$A_{8}$ & $\mathbf{M}$ & $34 / 12$ & 0.35 & $34 / 12$ & 66 \\
\hline$A_{9}$ & $\mathbf{M}$ & $8 / 12$ & 1.2 & $8 / 12$ & 330 \\
\hline$A_{10}$ & $\mathrm{~F}$ & $8^{4} / 12$ & 1.2 & $8^{4} / 12$ & 880 \\
\hline$B_{1}$ & $\mathrm{M}$ & $3 / 12$ & 195 & - & - \\
\hline$B_{2}$ & $\mathrm{~F}$ & - & - & $8 / 12$ & 342 \\
\hline$B_{3}$ & F & $4^{3} / 12$ & 73 & - & - \\
\hline$B_{4}{ }^{2}$ & $\mathbf{M}$ & 9 & 261 & $10^{7} / 12$ & 3,200 \\
\hline$B_{5}^{2}$ & $\mathbf{M}$ & 14 & 231 & $15^{7} / 12$ & 5,200 \\
\hline$B_{6}^{3}$ & $\mathrm{~F}$ & $2 / 12$ & 125 & $3 / 12$ & 1,000 \\
\hline$B_{7}{ }^{3}$ & $\mathrm{M}$ & 4 & 11 & $5^{1} / 12$ & 1,330 \\
\hline$B_{8}{ }^{3}$ & $\mathrm{~F}$ & 5 & 16 & $6^{1 / 12}$ & 4,400 \\
\hline$B_{9}$ & $\mathrm{~F}$ & 8 & 90 & - & - \\
\hline$B_{10}$ & $\mathrm{~F}$ & - & - & 13 & 11,400 \\
\hline $\mathrm{B}_{11}$ & $\mathbf{M}$ & $8^{3} / 12$ & 24 & - & - \\
\hline$B_{12}^{4}$ & $\mathrm{M}$ & $9^{3} / 12$ & 40 & $9^{3} / 12$ & 6,400 \\
\hline$B_{13}^{4}$ & $\mathrm{M}$ & $67 / 12$ & 15 & $6 \% / 12$ & 3,000 \\
\hline$B_{13}$ & M & $68 / 12$ & 6.3 & $68 / 12$ & 900 \\
\hline$C_{1}$ & $\mathrm{M}$ & - & - & $61 / 12$ & $1,9002,800^{5}$ \\
\hline$C_{2}$ & $\mathbf{M}$ & - & - & $75 / 12$ & $1,3003,400^{5}$ \\
\hline$C_{3}$ & $\mathbf{F}$ & - & - & $85 / 12$ & $9701,250^{5}$ \\
\hline$C_{4}$ & $\mathrm{~F}$ & - & - & $74 / 12$ & $5402,400^{5}$ \\
\hline
\end{tabular}

${ }_{1} A_{1}-A_{10}$ : normal children; $B_{1}-B_{13}$ : patients with $\mathrm{CAH} ; C_{1}-C_{4}$ : patients with PP.

2, 3,4 Siblings.

${ }^{5}$ After 3 days of HCG stimulation, 3,000 U/24 h.

The determination of testosterone in urine was carried out with ${ }^{14} \mathrm{C}$-labeled acetic anhydride. A suitable volume of urine was buffered with acetate buffer, $\mathrm{pH} 4.8$, and incubated for $48 \mathrm{~h}$ with $\beta$-glucuronidase (EC. 3.2.1.31) $(1,000 \mathrm{U} / \mathrm{ml})$ and sulfatase $(500 \mathrm{U} / \mathrm{ml})$ [47]. Neomycin, $200 \mu \mathrm{g} / \mathrm{ml}$, was added to inhibit the growth of microorganisms. No preextraction was carried out, as part of the testosterone glucuronide can be hydrolzyed by the glucuronidase activity that is present in the urine [4]. After ether extraction and washing of the crude extract, a preliminary purification was carried out on silica gel (silica gel Merck; $<0.08 \mathrm{~mm}$ with $25 \%$ water). Testosterone was eluted from the column with $\mathrm{CH}_{2} \mathrm{Cl}_{2}$ in ligroin. Step by step the $\mathrm{CH}_{2} \mathrm{Cl}_{2}$ concentration was raised by $10 \%$ with collection of $10-\mathrm{ml}$ fractions.

Usually testosterone was eluted at the $70 \%$ step. After a gradient elution on $\mathrm{Al}_{2} \mathrm{O}_{3}$ and paper chromatography according to the method of CAMAcHo and $\mathrm{Mr}$ GEON [2], the extract was acetylated with ${ }^{14} \mathrm{C}-\mathrm{Ac}_{2} \mathrm{O}$. The acetate then was purified by thin-layer chromatography (TLC) (ether-dimethylformamide, 99:1) on silica gel $\mathrm{H}$ (Merck), and by paper chromatography using a propyleneglycol-methylcyclohexane system, or TLG using benzene-ethylacetate, 80:20. With excretions of $<1 \mu \mathrm{g} / 24 \mathrm{~h}$ it was necessary to use a chemical modification as well to obtain a constant ${ }^{14} \mathrm{C} /{ }^{3} \mathrm{H}$ ratio. In this case, the purified testosterone 
acetate was dissolved in $1 \mathrm{ml}$ ice-cold methanol, to which $20 \mathrm{mg} \mathrm{NaBH}_{4}$ had been added. After $2 \mathrm{~min}$, $1 \mathrm{ml} \mathrm{50 \%} \mathrm{acetic} \mathrm{acid} \mathrm{was} \mathrm{added} \mathrm{to} \mathrm{decompose} \mathrm{the}$ $\mathrm{NaBH}_{4}$. The solution was diluted with $10 \mathrm{ml}$ distilled water and the reaction product extracted with ether. The resulting mixture of $3 \alpha$ and $3 \beta \mathrm{OH} \Delta^{4}$ steroids was chromatographed in the TLG system chloroformacetone, 95:5, and after elution was counted in a liquid scintillation spectrometer [48]. The recovery was calculated by addition of a known amount of $\left(1,2-{ }^{3} \mathrm{H}\right)$ testosterone to the urine using standard double isotope derivative methods.

Production rates of testosterone in urine were estimated in the following way: $0.5-1 \mu \mathrm{Ci}\left(1,2-{ }^{3} \mathrm{H}\right)$ testosterone was administered intravenously as described earlier [3]. Forty-eight hour urine collections were made. By adding a known amount of $\left(4-{ }^{14} \mathrm{C}\right)$ testosterone to the urine of the patient that had received an intravenous dose of $\left(1,2-{ }^{3} \mathrm{H}\right)$ testosterone, excretion as well as production can be calculated as follows: Just before the acetylation procedure the ${ }^{14} \mathrm{C} /{ }^{3} \mathrm{H}$ ratio $\left(R_{1}\right)$ was measured. The same was done after purification of the testosterone acetate $\left(R_{2}\right)$. The ratio of $\left(4-{ }^{14} \mathrm{C}\right)$ and $\left(1,2-{ }^{3} \mathrm{H}\right)$ testosterone must be constant and equal to $R_{1}$, apart from a small isotope-fractionation effect. Any deviation from this ratio is caused by the ${ }^{14} \mathrm{C}$-acetyl group, attached to the testosterone.

If $x \mathrm{dpm}$ of ${ }^{14} \mathrm{G}$ are counted in the final sample and $y \mathrm{dpm}$ of ${ }^{3} \mathrm{H}$, then $x / y=\mathrm{R}_{2}$. The contribution from the ${ }^{14} \mathrm{C}$-acetyl group to $x$ is $\left(\mathrm{R}_{2}-\mathrm{R}_{1}\right) y$, which is a measure of the amount of testosterone present (in micrograms). The contribution of the $\left(4-{ }^{14} \mathrm{C}\right)$ testosterone is $x-\left(\mathrm{R}_{2}-\mathrm{R}_{1}\right) y$ or, simplified, $y \mathrm{R}_{1}$. The recovery of testosterone throughout the procedure can be found easily by this method.

Next the specific activity (with regard to ${ }^{3} \mathrm{H}$ ) and the amount of testosterone in the urine sample are calculated. From the specific activity (with regard to ${ }^{3} \mathrm{H}$ ) the production rate of testosterone can be found. For clarity the following typical but fictitious example is given: Assume that following the intravenous administration of $2 \times 10^{6} \mathrm{dpm}\left(1,2-^{3} \mathrm{H}\right)$ testosterone $1 \%$ of the dose is excreted as testosterone glucuronide in a $48-\mathrm{h}$ period. If 0.25 of the total urinary volume is used for the estimation, $5,000 \mathrm{dpm}$ will be derived from $\left(1,2-{ }^{3} \mathrm{H}\right)$ testosterone. $\left(4-{ }^{14} \mathrm{C}\right)$ Testosterone, 8,000 $\mathrm{dpm}$, is added. At the end of the purification procedure and before acetylation, $3,500 \mathrm{dpm}\left(1,2-{ }^{3} \mathrm{H}\right)$ testosterone and $5,600 \mathrm{dpm}\left(4-{ }^{14} \mathrm{C}\right)$ testosterone (or $70 \%$ ) are recovered.

$$
\mathrm{R}_{1}=\frac{5,600}{3,500}=1.6
$$

Acetylation and the following purification procedure cause a further loss of $50 \%: 1,750 \mathrm{dpm}{ }^{3} \mathrm{H}$ will be recovered. Since $R_{1}$ is constant, one can calculate that $1.6 \times 1,750=2,800 \mathrm{dpm}$ of the total number of $\mathrm{dpm}$ ${ }^{14} \mathrm{C}$ is $\left(4-{ }^{14} \mathrm{C}\right)$ testosterone. Overall recovery throughout the procedure is :

$$
\frac{2,800}{8,000} \times 100 \%=35 \%
$$

If a total of $5,250 \mathrm{dpm}{ }^{14} \mathrm{C}$ is counted, the difference $5,250-2,800=2,450$ which represents the contribution by the ${ }^{14} \mathrm{C}$-acetyl group. From the known specific activity of the acetic anhydride, here arbitrarily chosen to be $4,900 \mathrm{dpm} / \mu \mathrm{g}$ testosterone, it follows that the amount of testosterone is $0.5 \mu \mathrm{g}$. The specific activity of the urinary testosterone is:

$$
1,750 / 0.5=3,500 \mathrm{dpm} / \mu \mathrm{g}
$$

The urinary production rate equals :

$$
\frac{2 \times 10^{6}}{3,500}=570 \mu \mathrm{g} / 24 \mathrm{~h}
$$

The rate of excretion equals:

$$
0.5 \times \frac{100}{35} \times 4=5.7 \mu \mathrm{g} / 24 \mathrm{~h}
$$

The ${ }^{3} \mathrm{H} /{ }^{14} \mathrm{C}$ ratio of the purified testosterone (before the acetylation) is a critical value in our calculations. Steroids, ${ }^{3} \mathrm{H}$-labeled, other than testosterone, that might be present at this stage, would introduce considerable errors. The purification procedure, however, is rather elaborate and efficient. As reported [2], the infrared spectrum of the final product is identical with that of pure testosterone. In our own investigations also, we never found a significant decrease in the ${ }^{3} \mathrm{H} /{ }^{14} \mathrm{C}$ ratio upon further chromatography or nonradioactive derivative formation.

Pregnanetriol was estimated according to FoTHERBY and Love [8]; $\mathrm{Al}_{2} \mathrm{O}_{3}$ was obtained commercially [49] (Brockman activity 1, pH 6; 100-200 mesh). Three and one-half milliliters of water were added directly to $96.5 \mathrm{~g}$ of $\mathrm{Al}_{2} \mathrm{O}_{3}$ instead of exposing the $\mathrm{Al}_{2} \mathrm{O}_{3}$ to a water-saturated atmosphere. 17-Ketosteroids were estimated according to the method of PExERson and Pierce [31].

\section{Results}

The results are shown in tables $\mathrm{I}$ and II and figures $1,2,3$, and 4 . The excretion of testosterone in normal children varied from 0.3 to $6.3 \mu \mathrm{g} / 24 \mathrm{~h}$ with a mean of $2.1 \mu \mathrm{g}$.

Production of testosterone in the same children varied from 16 to $880 \mu \mathrm{g} / 24 \mathrm{~h}$, with a mean of $274 \mu \mathrm{g} /$ $24 \mathrm{~h}$. Other figures on excretion were published by VestergaARD [42] who investigated 10 children aged 4-8 years and found that they excreted $0.1-0.8 \mu \mathrm{g} /$ 


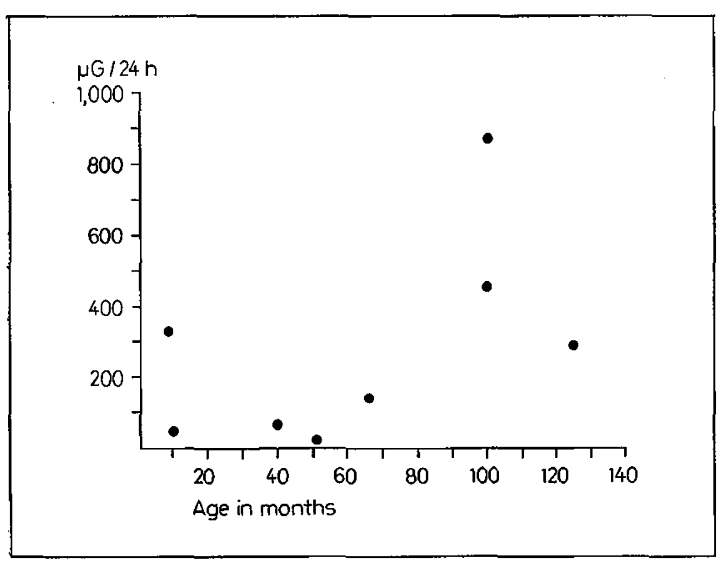

Fig. 1. Testosterone production of normal children as a function of age. No linear correlation.

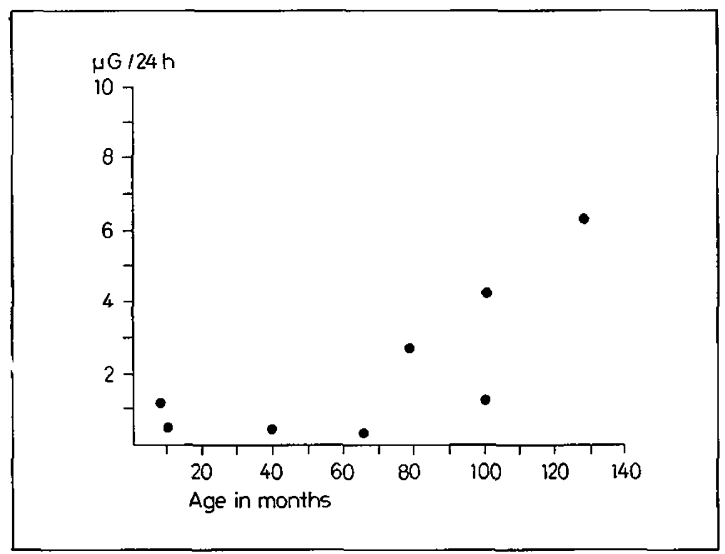

Fig. 2. Testosterone excretion of normal children as a function of age. A linear correlation exists.

Fig.3.

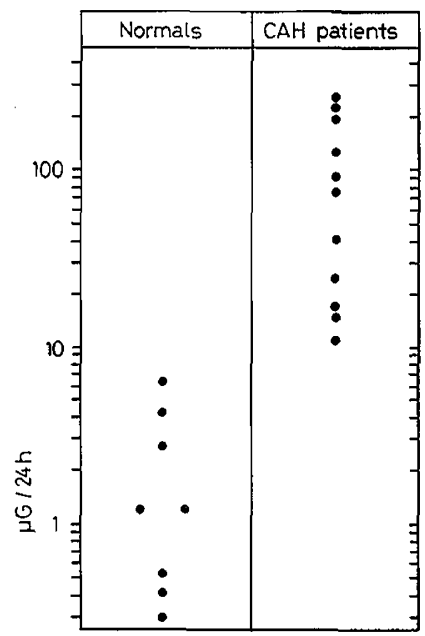

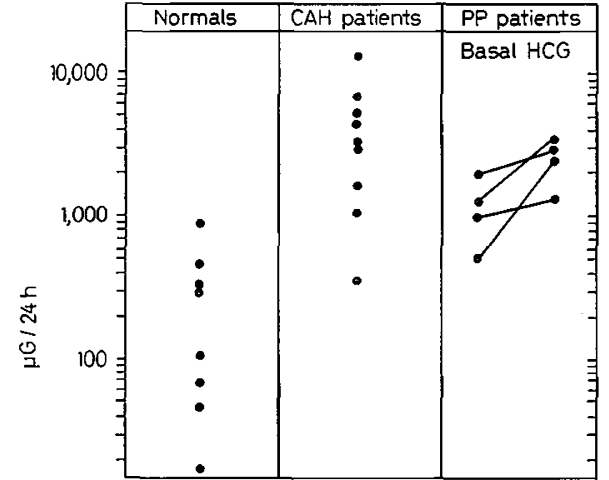

Fig.4. Testosterone production in children with CAH, in children with $\mathrm{PP}$, and in normal children. After administration of HCG an increase in testosterone production occurs. Logarithmic representation.

$24 \mathrm{~h}$. The minimal excretion that can be estimated with this method seems to be about $0.02 \mu \mathrm{g}$. GuPta [11] investigated children with a calendar age of 8-12 years. He found that excretion rates in his patients were $0-14 \mu \mathrm{g} / 24 \mathrm{~h}$. The sensitivity of this method is about $4 \mu \mathrm{g} / 24 \mathrm{~h}$. KNORR $[19,20]$ investigated a group of about 30 boys, aged 3-8 years, and obtained a mean excretion rate of $4 \mu \mathrm{g} / 24 \mathrm{~h}$. His lowest level, differing from zero, is $1-2 \mu \mathrm{g} / 24 \mathrm{~h}$. Our data do not reveal a linear correlation between age and testosterone production. There is a significant linear correlation, however, between age and testosterone excretion $(r=$ 0.75 ); the regression coefficient is 0.037 (fig. 2 ). It is possible, however, that a nonlinear correlation would appear if more data became available.

In those cases where excretion as well as production were measured at the same time $\left(A_{5}-A_{10}\right)$, excretion appeared to be $0.14-1.1 \%$ of production, with a mean of $0.6 \%$.

Children with $\mathrm{CAH}\left(B_{1}-B_{13}\right)$ have markedly elevated levels of testosterone production and excretion compared with normal children $(P<0.001)$. It is remarkable that in three cases $\left(B_{12}, B_{13}\right.$ untreated, and $B_{13}$ while he was on treatment), when the excretionto-production ratio could be determined from the same urine, the mean ratio was $0.6 \%$, as found in normal children.

Most of the data presented were obtained from children receiving medication up until 1 week before the investigation. Only four of them $\left(B_{6}, B_{10}, B_{12}\right.$, and $\left.B_{13}\right)$ had not been treated before. One boy $\left(B_{13}\right)$, first studied before treatment was begun, showed normal

Fig.3. Testosterone excretion in children with GAH and in normal children. Logarithmic representation. 
values for excretion and production of testosterone when reinvestigated (while he was on treatment) 1 month after initiation of therapy with prednisone.

In our patients with idiopathic PP, mean testosterone production differed significantly from normal $(P<0.01)$. There was no significant difference, however, between patients with $\mathrm{CAH}$ and PP $(P>0.05)$. After stimulation with HCG, a further increase of testosterone production was observed in the four patients with PP.

\section{Discussion}

Our results confirm that young prepubertal children produce and excrete small amounts of testosterone. At the moment it is difficult, however, to state with certainty to what extent these results represent the amount of biologically active testosterone. The most direct measure of this activity is the plasma concentration and production rate (BPR) of testosterone. The $\mathrm{BPR}$ is defined as the product of metabolic clearance rate and the blood concentration of the hormone [7]. The BPR is, therefore, directly dependent on levels of testosterone in the plasma, while the urinary production rate (UPR), calculated from the cumulative specific activity of testosterone in the urine, has the disadvantage of being a combination of testosterone secretion, testosterone production, and testosterone glucuronide production. This last component can be very important. Thus, KorenMan and LIPSETT [22, 23] showed that in women, a large part of testosterone which is derived from androstenedione and dehydroepiandrosterone is immediately conjugated to glucuronide before appearing in the bloodstream.

The circulating free testosterone originates from two organs: the adrenals and the gonads. In the adult male, the direct secretion by the testes is by far the most important source; BPR and UPR are of the same magnitude. In the female, free testosterone is derived from the adrenals as well as from the ovaries, partly directly, partly through peripheral formation, especially from androstenedione $[10,26]$. This free testosterone in plasma, originating from androstenedione is produced mainly outside the liver [15]. The direct secretion of testosterone by the normal human adrenal gland is most probably very small [43], even though this organ has the required enzyme systems and adrenal homogenates are able to produce testosterone [18].

In normal children, testosterone probably originates from the adrenal glands and the gonads. The fact that prepubertal boys have higher concentrations in plasma than girls [9] suggests the dominating influence of the testes, although the total secretion and production is very small.
It might be possible, as there is a linear correlation between the excretion of testosterone glucuronide and age, that testosterone plays an increasing role in the growth and development of the prepubertal child.

The excretion and production in the two very young children ( $<12$ months) was relatively high. Further studies in this age group will be necessary.

A few series of patients with GAH have been published; rates of production and excretion of testosterone were determined and were found to be elevated [25, 36]. Korenman $e t$ al. [21] describe a case with only a slightly increased testosterone UPR and one case with an elevated UPR.

Our results for rates of excretion and production of testosterone in patients with $\mathrm{CAH}$ and PP show once again that in these cases elevated testosterone production and symptoms of virilization appear together. The clinically observed symptoms of virilization in all our patients with $\mathrm{CAH}$ can easily be explained, because of the high testosterone production. For some years virilisation in GAH patients was thought to be caused by testosterone. Until recently, however, there was no certain proof for this.

Direct proof of the occurrence of testosterone-in CAH was obtained by GANDY et al. [10]. In five female patients, they found testosterone concentrations in plasma that were 10-25 times higher than normal. The androstenedione concentrations averaged approximately $0.13 \mu \mathrm{g} / 100 \mathrm{ml}$. Similar findings were published by Rivarola et al. [34]. They too found highly elevated levels of testosterone and androstenedione in plasma in all their patients, and elevated levels of dehydroepiandrosterone in most of them. About $50 \%$ of this testosterone was derived from the androstenedione.

The transfer constants between testosterone and androstenedione had normal values and also the metabolic clearance rates of both steroids fell in the normal range. If one applies this information to the data of GANDY et al. [10] an even higher percentage of testosterone derived from androstenedione is found.

In 1967, the findings of RIVARola et al. [34] were corroborated by HorTon [12], so we can conclude that a large percentage of the testosterone in plasma, in children with a steroid 21-hydroxylase deficiency originates from other steroids in the plasma, such as androstenedione and dehydroepiandrosterone. Direct secretion of testosterone seems to be only slightly elevated. The situation in children with $\mathrm{PP}$ is less clear, and to our knowledge, no exact data about the origin of the testosterone have been published. Very little is known about testosterone excretion and production as well. One of the few studies was carried out by NEw et al. [30] who found an increased testosterone production in a 3-year-old boy. In our four patients with 
idiopathic $\mathrm{PP}$, testosterone production was high, and in the same range as found in the patients with CAH. A large part of the testosterone is probably derived directly from gonads and adrenals. The same situation exists in many women with hirsutism [1]. After stimulation with HCG a further increase of testosterone production in the four patients with PP was observed. Most probably this testosterone originated from the gonads of the children, for though it has been found [35] that the human adrenal glands are able to react to HGG with a resultant raised testosterone production, this reaction is not very marked.

It has been shown $[33,34]$ that in patients with CAH caused by 21-hydroxylase deficiency, a discrepancy exists between blood production rate and urinary production rate of testosterone, the latter being much higher. This discrepancy arises because there are precursors for testosterone glucuronide in urine that are other than the precursors for testosterone in plasma. The UPR of testosterone, therefore, reflects the total androgen production. The same steroids (testosterone, androstenedione, and dehydroepiandrosterone) that contribute to the excretion of testosterone glucuronide in the urine also contribute to the levels of free testosterone in plasma although in different proportions.

Investigators should be aware that excretion of sterone in plasma, although in different proportions. ure of the biological activity of testosterone. This is also the case with the BPR. MAHESH [27] pcints out that variations exist in the sensitivity of the organism towards testosterone, and one must take into account that a given dose does not always elicit the same reaction.

Binding to protein and erythrocytes probably plays an important role.

\section{Summary}

Excretion, or production, or both, of testosterone was measured by an isotope derivative method in three series of children: group $A$, normal children; group $B$, patients with CAH caused by a steroid 21-hydroxylase deficiency; and group $C$, children with PP.

The range of excretion and production values of testosterone in a group of prepubertal normal children was given. Comparison of group $A$ with group $B$ and group $C$ indicated elevated androgen production in the last two groups. The significance of these findings was discussed.

\section{References and Notes}

1. Bardin, C.W. and Lipsett, M.B.: Testosterone and androstenedione production and interconver- sion rates in hirsute women; in: J.TAMM: Testosterone, p. 226 (Thieme, Stuttgart 1968.

2. Gamacho, A.M. and Migeon, C.J.: Isolation, identification and quantitation of testosterone in the urine of normal adults and in patients with endocrine disorders. J.clin. Endocrin. 23: 301 (1963).

3. Degenhart, H.J.; Visser, H.K.A.; Wilmink, R. and GRougrs, W.: Aldosterone and cortisol secretion rates in infants and children with congenital adrenal hyperplasia, suggesting different 21-hydroxylation defects in 'salt-losers' and 'non salt-losers'. Acta endocrin., Kbh. 48: 587 (1965).

4. Degenhart, H.J.; Visser, H. K.A. and Wilmink, B.: Unpublished observations.

5. Desaulles, P.A.: in: F.Gross: Protein metabolism, p. 196 (Springer, Berlin 1962).

6. Dorfman, R.J.: Discussion. Recent Progr. Hormone Res. 22: 272 (1962).

7. Erk-Nes, K.B. and Hall, P.F.: Secretion of steroid hormones in vivo. Vitamins Hormones, N.Y. 23: 153 (1965).

8. Fotherbx, K. and Love, D.N.: A modified method for the estimation of pregnanetriol in urine. J. Endocrin. 20: 157 (1960).

9. Fraster, S.D. and Horton, R.: Androgens in the peripheral plasma of prepubertal children and adults. Steroids 8: 777 (1966).

10. Gandx, H. M. ; Moody, C. B. and Peterson, R.E. : Androgen levels in ovarian and adrenal venous plasma. Proc. of the 6th Pan-American Congr. Endocrinology, p. 223 (Excerpta Medica Foundation, Amsterdam 1966).

11. Gupta, D.: Separation and estimation of testosterone and epitestosterone in the urine of pre-pubertal children. Steroids 10: 457 (1967).

12. Hor'on, R.: Androgen dynamics in women with virilization; in: J.TAMM: Testosterone, p.221 (Thieme, Stuttgart 1968).

13. Horton, R. and MANN, K.: Estimation of androstenedione and testosterone in plasma with ${ }^{35} \mathrm{~S}$ thiosemicarbazide (Abstract). Second Int. Congr. Hormonal Steroids, p.131 (Excerpta Medica Foundation, Amsterdam 1966).

14. Horton, R.; Rossner, J. and Forsham, P.: Testosterone production rate: studies on the adrenal cortex. Proc. Soc. exp. Biol., N.Y. 114: 400 (1963).

15. Horton, R. and TAIT, J.F.: Testosterone in plas$\mathrm{ma}$, the relative role of direct secretion and peripheral production from precursors (Abstract). Second Int. Congr. Hormonal Steroids, p. 149 (Excerpta Medica Foundation, Amsterdam 1966).

16. Hudson, B.; Coghlan, J.; Dulmanis, A. and EKKEL, J.: Measurement of testosterone secretion. 
The Endocrine Society. Progr. of the 44th Meeting, Chicago, IL, June 1962.

17. Ismail, A.A.A. and Harkness, R.A.: A method for the estimation of urinary testosterone. Biochem. J. 99: 717 (1966).

18. Kase, N. and KowaL, J.: In vitro production of testosterone in a human adrenal homogenate. J.clin. Endocrin. 22: 925 (1962).

19. KNORR, D.: Über die Ausscheidung von freiem und Glucuronsäure gebundenem Testosteron im Kindes- und Reifungsalter. Acta endocrin., Kbh. 54: 215 (1967).

20. KNORR, D.: Testosterone excretion in boys treated with HCG for cryptorchidism; in: J.TAMm: Testosterone, p. 190 (Thieme, Stuttgart 1968).

21. Korenman, S. G.; Kirschner, M.A. and Lipsett, M.B.: Testosterone production in normal and virilized women and in women with the SteinLeventhal syndrome or idiopathic hirsutism. J. clin. Endocrin. 25: 798 (1965).

22. Korenman, S. G. and Lipsett, M.B.: Direct peripheral conversion of dehydroepiandrosterone to testosterone glucuroniside. Steroids 5: 509 (1965).

23. Korenman, S. G. and Lipsett, M.B.: Is testosterone glucuroniside uniquely derived from plasma testosterone? J. clin. Invest. 43: 2125 (1964).

24. Korenman, S. G.; Wilson, H. and Lipsett, M. B. : Testosterone production rates in normal adults. J. clin. Invest. 42: 1753 (1963).

25. Lim, N.Y. and Dingman, J.F.: Measurement of testosterone excretion and production rate by glass paper chromatography. J.clin. Endocrin. 25: 563 (1965).

26. Lipsett, M.B.: Theoretical considerations of virilization. Proc. of the 6th Pan-American Congr. Endocrinology, p. 211 (Excerpta Medica Foundation, Amsterdam 1966).

27. MAfesh, V.B.: Androgen secretion and virilization. Proc. of the 6th Pan-American Congr. Endocrinology, p. 213 (Excerpta Medica Foundation, Amsterdam 1966).

28. Mc Roberts, J.W.; Olson, A.D. and Herrmann, W.L.: Determination of urinary testosterone and epitestosterone in men, women and children. Clin. Chem. 14: 565 (1968).

29. Migeon, G.J.; Rivarola, M.A. and Saez, J. M.: Secretion of testosterone, androstenedione and dehydroepiandrosterone in various endocrinopathies; in: J.TAMm: Testosterone, p. 176 (Thieme, Stuttgart 1968).

30. New, M.; Pitr, P. and Peterson, R. E. : Testosterone production in a 3 year old male with isosexual precocity. J. Pediat. 63: 703 (1963).

31. Peterson, R.E. and Pierce, C.E.: Methodology of urinary 17 -ketosteroids; in: SUNDERMAN and
SUNDERMAN: Lipids and the steroid hormones in clinical medicine, p. 158 (Lippincott, Philadelphia 1960).

32. Rivarola, M.A. and Migeon, C.J.: Determination of testosterone and androst-4-ene-3, 17-dione concentration in human plasma. Steroids 7: 103 (1966).

33. Rivarola, M.V.; Saez, J.M.; Meyer, W.J.; Jenkins, M.E. and Migeon, G.J.: Metabolic clearance rate and blood production rate of testosterone and androst-4-ene-3, 17-dione under basal conditions, ACTH and HCG stimulation. Comparison with urinary production rate of testosterone. J. clin. Endocrin. 26: 1208 (1966).

34. Rivarola, M.A.; Saez, J. M. and Migeon, G.J.: Studies of androgens in patients with congenital adrenal hyperplasia. J.clin. Endocrin. 27: 624 (1967).

35. ROSNER, J.M.: In vivo and in vitro studies of virilizing syndromes; Proc. of the 6th Pan-American Congr. Endocrinology, p.231 (Excerpta Medica Foundation, Amsterdam 1966).

36. Rosner, J. M.; Conte, N. F.; Briggs, J.H.; Ghao, P.Y.; Sudman, E. M. and Forsham, P.: Determination of urinary testosterone by chromatography and colorimetry: Findings in normal subjects and in patients with endocrine diseases. J. clin. Endocrin. 25: 95 (1965).

37. Surace, M.; Luisi, M.; Moneta, E.; Marescottr, V. and Polvani, F.: in: A.Vermeulen and D. EXLEY: Androgens in normal and pathological conditions, p. 16 (Excerpta Medica Foundation, Amsterdam 1966).

38. Tait, J.F. and Horton, R.: Some theoretical considerations on the significance of the discrepancy in urinary and blood production rate estimates of steroid hormones, particularly in those of testosterone in young women. Steroids $4: 365$ (1964).

39. Van de Wiele, R.L.; Macdonald, P. G.; GurPIDE, E. and Lieberman, S. : Studies on the secretion and interconversion of the androgens. Recent Progr. Hormone Res. 23: 275 (1963).

40. Van der Molen, H.J.; Groen, D. and Peterse, A.: Measurement of testosterone in plasma and urine using gas-liquid chromatography; in: A. Vermeulen and D. Exley: Androgens in normal and pathological conditions, p. 1 (Excerpta Medica Foundation, Amsterdam 1966).

41. Vermeulen, A.: Urinary excretion of testosterone; in: A.Vermeulen and D. Exley: Androgens in normal and pathological conditions, p. 71 (Excerpta Medica Foundation, Amsterdam 1966).

42. VestergaArd, P.; RaAbo, E. and Vedsø, S.: Determination of urinary testosterone in men, 
women and children. Glin.chim. Acta 14: 540 (1966).

43. Wieland, R.G.; de Courcy, G.; Levy, R.P.; Zala, A. and Hirschman, H.: $\mathrm{C}_{19} \mathrm{O}_{2}$ Steroids and some of their precursors in blood from normal human adrenals. J. clin. Invest. 44: 159 (1965).

44. Radiochemical Centre, Amersham, England.

45. Radiochemical Centre.

46. New England Nuclear Corporation, Boston, MA.

47. Suc d'Helix Pomatia, Industr. Biol. Franç.

48. Model nos. 725 and Mark I, Nuclear-Chicago Corporation, Des Plaines, IL.

49. Hopkins and Williams.
50. Informed consent was obtained for all subjects in this study.

51. Supported in part by a grant from the Foundation for Basic Medical Research (FUNGO).

52. The authors were formerly at the Department of Pediatrics, State University of Groningen, Groningen, The Netherlands.

53. Request for reprints should be addressed to: H.J. Degenhart, Ph.D., Department of Pediatrics, Rotterdam Medical School, Sophia Children's Hospital and Neonatal Unit, 160 Gordelweg, Rotterdam (The Netherlands).

54. Accepted for publication December 10, 1969. 